\title{
Reversible signal regulation system of 19F NMR by redox reactions using a metal complex as a switching module.
}

\section{$\operatorname{AUTHOR}(\mathrm{S})$ :}

Tanaka, Kazuo; Kitamura, Narufumi; Takahashi, Yuichi; Chujo, Yoshiki

\section{CITATION:}

Tanaka, Kazuo ... [et al]. Reversible signal regulation system of 19F NMR by redox reactions using a metal complex as a switching module.. Bioorganic \& medicinal chemistry 2009, 17(11): 3818-3823

ISSUE DATE:

2009-06-01

URL:

http://hdl.handle.net/2433/123364

\section{RIGHT:}

Copyright @ 2009 Elsevier; この論文は出版社版でありません。引用の 際には出版社版をご確認ご利用ください。; This is not the published version. Please cite only the published version. 


\title{
Reversible Signal Regulation System of ${ }^{19}$ F NMR by Redox Reactions Using a Metal Complex as a Switching Module
}

\author{
Kazuo Tanaka, Narufumi Kitamura, Yuichi Takahashi, and Yoshiki Chujo* \\ Department of Polymer Chemistry, Graduate School of Engineering, Kyoto University, Katsura, Nishikyo-ku, Kyoto, 615-8510, Japan
}

\begin{abstract}
We present here the reversible signal regulation of ${ }^{19} \mathrm{~F}$ NMR using the transition metal complex as a switching module. Watersoluble fluorinated dendrimers containing ferrocene were synthesized as a probe, and the signal intensities of ${ }^{19} \mathrm{~F}$ NMR of the probes were monitored by changing the valence state of the ferrocene moiety. By oxidation of the ferrocene moiety, the relaxation of the nearby fluorine atoms was accelerated via the paramagnetic relaxation enhancement, as a result the ${ }^{19} \mathrm{~F}$ NMR signal from the probe was significantly decreased. The reduction of the ferrocenium cation of the probe recovered the signal intensity. Finally, in combination with the difference of the fluorescence quenching ability between ferrocene and ferrocenium cation, we constructed the multimodal ${ }^{19} \mathrm{~F}$ NMR / fluorescence probe based on the redox switching system. () 2010 Elsevier Science. All rights reserved
\end{abstract}

\section{Introduction}

Magnetic resonance imaging (MRI) is one of the powerful diagnostic tools in modern clinical medicine, and it can provide noninvasive, site-selective three-dimensional examination of biological events in living organisms with a contrast agents. ${ }^{19} \mathrm{~F}$ MRI using fluorinated compounds as the contrast agents has been paid attentions because less existence of endogenous fluorine atom gives the high signal to noise ratio in the images. ${ }^{1-6}$ In addition, much interest of recent researchers has directed to construct the system for monitoring the vital reactions using the stimuli-responsive molecules as MRI contrast agents, and several groups have reported the switching system of the ${ }^{19} \mathrm{~F}$ NMR signals for the detection of the enzymatic activity or the microenvironmental alteration. ${ }^{7-13}$

The sensitivity of NMR signals was significantly influenced by paramagnetic relaxation enhancement (PRE) caused from the nearby paramagnetic metal ions such as $\mathrm{Fe}^{3+}$ or $\mathrm{Gd}^{3+}$ via the acceleration of the relaxation time. ${ }^{7}$ The magnetism of ferrocene derivatives is dominated by the valence state of the Fe center. ${ }^{14-16}$ Neutral ferrocene derivatives display diamagnetism due to the closed shell electron structure. On the other hand, the ferrocenium cation can increase the relaxation rate of the solvent molecules via PRE caused from the unpaired electron. ${ }^{15}$ In particular, the switching of the valence state of ferrocene derivatives can reversibly proceed in aqueous media, and some of ferrocenium cation derivatives can exist stably in vivo. ${ }^{16}$ Thus, ferrocene derivatives are promised to be the reversible switch to regulate the signal intensity of NMR for monitoring redox-active species or environment under biological conditions.

Herein, we describe the reversible regulation system for ${ }^{19} \mathrm{~F}$ NMR signals by the redox reactions. The water-soluble redox sensor for ${ }^{19} \mathrm{~F}$ NMR tethered ferrocene as the signal switching module was synthesized as a probe (Scheme 1), and the signal intensities of ${ }^{19} \mathrm{~F}$ NMR of the probes can be controlled via the modulation of the valence state of the ferrocene moiety. By oxidation of the ferrocene moiety, the relaxation of the nearby fluorine atoms was enhanced, as a result the ${ }^{19} \mathrm{~F}$ NMR signal from the probe was significantly decreased. The reduction of the ferrocenium cation of the probe recovered the signal intensity. Furthermore, in combination with the difference of the fluorescence

\footnotetext{
${ }^{*}$ Corresponding author. Tel.: +81-75-383-2604; fax: +81-75-383-2605; e-mail: chujo@chujo.synchem.kyoto-u.ac.jp.
} 


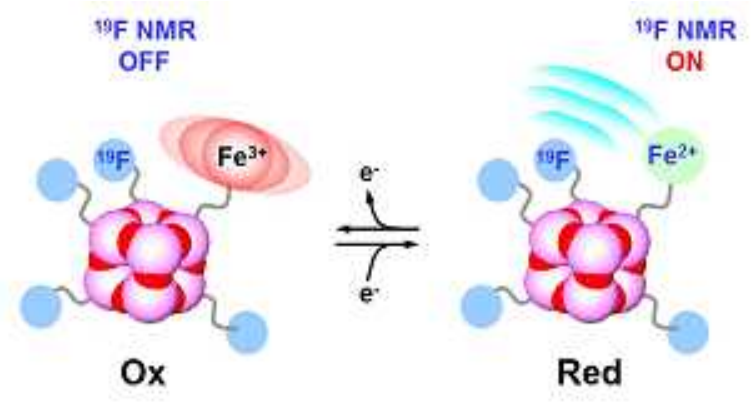

Scheme 1. Reversible redox chemosensor using ferrocene complex.

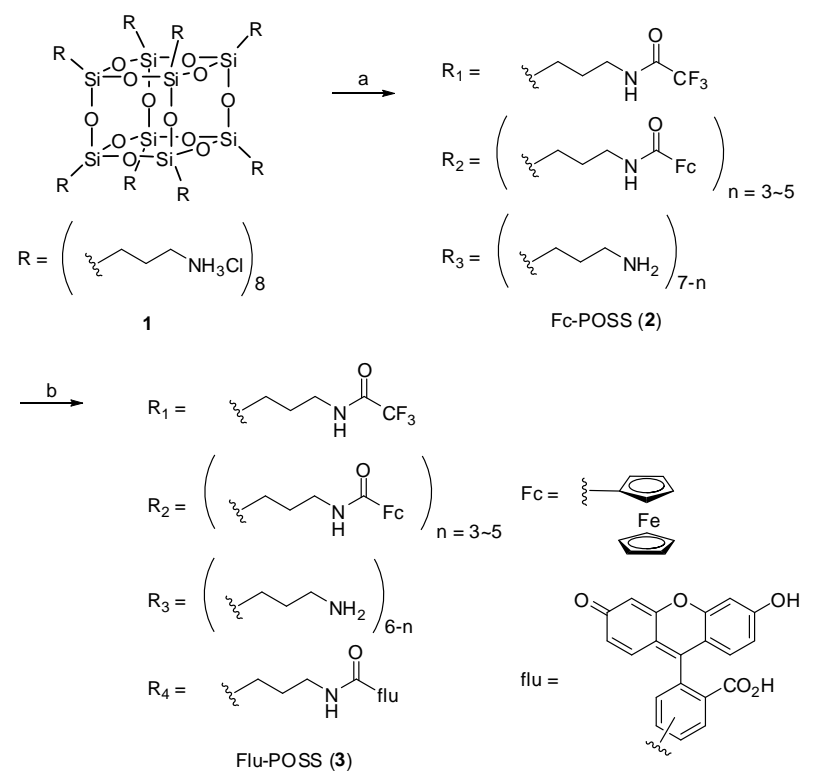

Scheme 2. Synthetic scheme of Fc-POSS and Flu-POSS. Reagents and Conditions: (a) i) ethyl trifluoroacetate, triethylamine, methanol, r.t., 3 h, ii) ferrocene carboxylic acid, DMT-MM, 72\%, r.t., $3 \mathrm{~h}$; (b) 5(6)fluorescein carboxylic acid, DMT-MM, methanol, $62 \%$, r.t., 3 h.

quenching ability between ferrocene and ferrocenium cation, we constructed the multimodal ${ }^{19} \mathrm{~F}$ NMR / fluorescence probe based on this redox switching system. To our knowledge, this is the first example using the metal complex as the reversible switch for ${ }^{19} \mathrm{~F}$ NMR signals.

\section{Results and Discussion}

\subsection{Synthesis of the POSS-based probes}

The chemical structures of the ferrocene-tethered redox probe (Fc-POSS) are shown in Scheme 1. The probe is consisting of three parts, which are the ferrocene moiety for the signal modulation, trifluoroacetyl groups for the ${ }^{19} \mathrm{~F}$ NMR signal, and cubic octameric polyhedral oligomeric silsesquioxanes (POSS) ${ }^{17-20}$ as a water-soluble scaffold for the assembly of signal molecules. ${ }^{11-13}$ PRE strongly depends on a distance between paramagnetic species and observed nuclei, therefore compact structure of POSS (ca. $1.5 \mathrm{~nm}$ diameter) compared to other water-soluble dendrimer such as a PAMAM dendrimer (2.9 $\mathrm{nm}$ diameter)

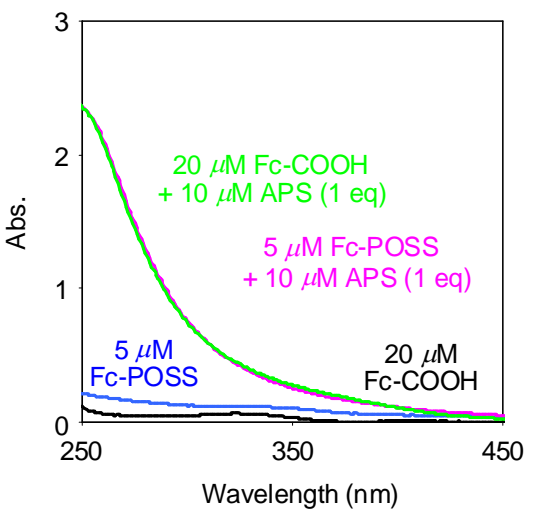

Figure 1. UV absorption spectra of the sample containing $5 \mu \mathrm{M} \mathrm{Fc-POSS}$ with (magenta line) or without (blue line) $10 \mu \mathrm{M}$ APS and $20 \mu \mathrm{M}$ ferrocene carboxylic acid with (green line) or without (black line) $10 \mu \mathrm{M}$ APS in $50 \mathrm{mM}$ sodium phosphate buffer $(\mathrm{pH}=7.0)$ at $25^{\circ} \mathrm{C}$.

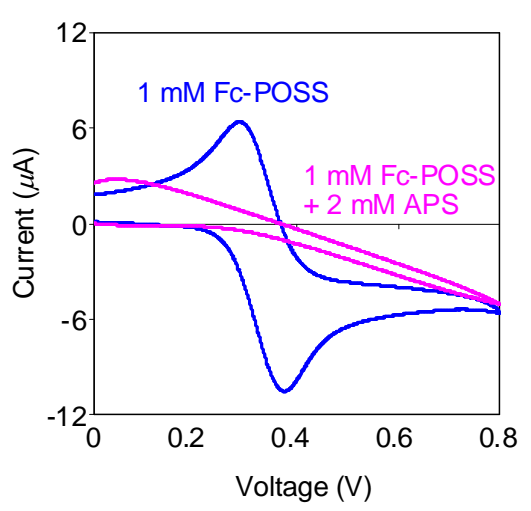

Figure 2. Cyclic voltammogram of $1 \mathrm{mM}$ Fc-POSS in the presence (magenta line) and absence (blue line) of $2 \mathrm{mM}$ APS.

has an advantage to be used as a scaffold for presenting PRE efficiently. ${ }^{7,21}$ The introduction of trifluoroacetyl groups and a ferrocence group into POSS was accomplished in good yield. ${ }^{22}$ The major product was identified with the modified POSS containing four ferrocene carboxylate groups from MALDI-TOF-MS spectra. The significant peak broadening following the decreasing of sensitivity of Fc-POSS was not observed by adding to BSA $(1 \mathrm{mg} / \mathrm{mL})$, the serum or the $\mathrm{pH}$ alteration between $\mathrm{pH} 5$ to 9 . These data suggest that undesired aggregation or non-specific adsorption of Fc-POSS could hardly exist in the measurements. In addition, the degradation of Fc-POSS was not observed after $24 \mathrm{~h}$ incubation at $37{ }^{\circ} \mathrm{C}$ at $\mathrm{pH} 7.0$ in the presence of protease $\mathrm{K}$. These results imply that ferrocene- and trifluoroacetylcontaining POSS probes might be applicable for sensing with ${ }^{19} \mathrm{~F}$ MRI under biological conditions.

\subsection{Oxidation of the probes}

In order to evaluate the generation of the ferrocenium cation-containing POSS ( $\mathrm{Fc}^{+}-\mathrm{POSS}$ ) via the oxidation, we used ammonium persulfate (APS) as an oxidizer to the ferrocene moiety because less absorption of APS in the UV and visible region can provide quantitative data from 
a

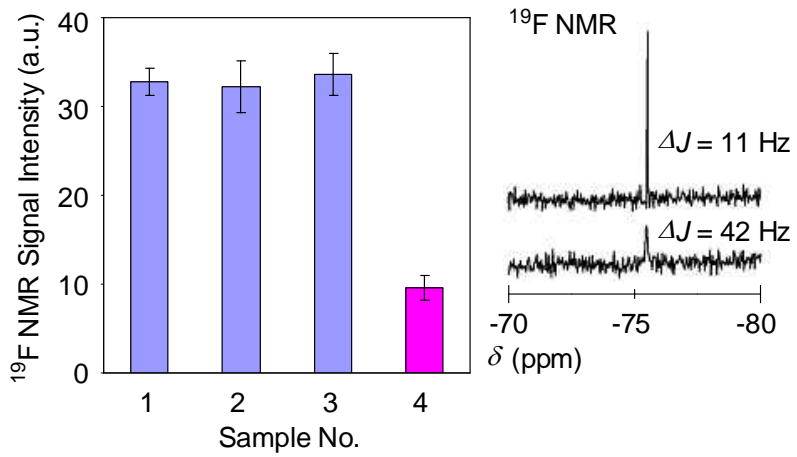

Figure 3. (a) ${ }^{19} \mathrm{~F}$ NMR signal intensities of fluorinated POSS $(1 \mathrm{mM})$ in the presence and absence of $2 \mathrm{mM}$ APS in $50 \mathrm{mM}$ sodium phosphate buffer $(\mathrm{pH}=7.0)$ at $25^{\circ} \mathrm{C}$. Sample 1 , the fluorinated POSS without the ferrocene moiety in the absence of APS; sample 2, the fluorinated POSS without the ferrocene moiety in the presence of APS and external ferrocene carboxylic acid (4 mM); sample 3, Fc-POSS in the absence of APS; sample 4, Fc-POSS in the presence of APS. Each experiment was performed in triplicate and the error bars represent SD values. (b) ${ }^{19} \mathrm{~F}$ NMR spectra of Fc-POSS (1 mM) with (upper) or without (lower) $2 \mathrm{mM}$ APS in $50 \mathrm{mM}$ sodium phosphate buffer $(\mathrm{pH}=7.0)$ at $25^{\circ} \mathrm{C}$.

optical analysis. From UV spectra of Fc-POSS $(5 \mu \mathrm{M})$ in $50 \mathrm{mM}$ sodium phosphate buffer $(\mathrm{pH}=7.0)$, the addition of $10 \mu \mathrm{M}$ APS gave rise to the absorption band in the range of 250-300 nm which corresponds to the LMCT absorbance band $\left({ }^{1} \mathrm{e}_{1 \mathrm{u}} \rightarrow{ }^{2} \mathrm{e}_{1 \mathrm{~g}}\right.$ ) of the ferrocenium cation (Figure 1). ${ }^{14}$ Cyclic voltammogram of Fc-POSS $(1 \mathrm{mM})$ showed the disappearing of the first oxidation peak of the ferrocene moiety of Fc-POSS $(+0.31 \mathrm{eV}$ vs $\mathrm{Ag} / \mathrm{AgCl})$ in the presence of $2 \mathrm{mM}$ APS (Figure 2). These results indicate that the oxidation of Fc-POSS should be effectively progressed by the addition of the equivalent of APS.

\subsection{Signal regulation with paramagnetic relaxation enhancement}

We evaluated the signal intensity of ${ }^{19} \mathrm{~F}$ NMR of the fluorinated POSS $(1 \mathrm{mM})$ in $50 \mathrm{mM}$ sodium phosphate buffer $(\mathrm{pH}=7.0)$ at $25{ }^{\circ} \mathrm{C}$ (Figure 3a). In the case of fluorinated POSS without the ferrocene moiety, the signal intensity was not influenced even by the externally addition of ferrocenium cation (Samples 1 and 2). The significant decreasing of ${ }^{19} \mathrm{~F}$ NMR signal of Fc-POSS was observed by the addition of APS to the solution (Samples 3 and 4). The signal height obtained from the sample containing $2 \mathrm{mM}$ APS decreased to $21 \%$ with broadening the half-width of the peak $(\Delta \Delta J=+31 \mathrm{~Hz}$, Figure $3 \mathrm{~b})$. These results indicate that the ferrocence moiety covalently attached to POSS should be responsible for the signal regulation of ${ }^{19} \mathrm{~F}$ NMR, and strong dependency of PRE by the valence state of ferrocenium cation in the probe.

We measured the longitudinal relaxation time $\left(\mathrm{T}_{1}\right)$ and the transverse relaxation time $\left(\mathrm{T}_{2}\right)$ of Fc-POSS in ${ }^{19} \mathrm{~F}$ NMR before and after oxidation. The $\mathrm{T}_{1}$ and $\mathrm{T}_{2}$ in the absence of APS were 0.673 and $0.660 \mathrm{~s}$, respectively. In contrast, the values of relaxation times of $\mathrm{Fc}^{+}$-POSS were not determined, because of shorter relaxation times and the low

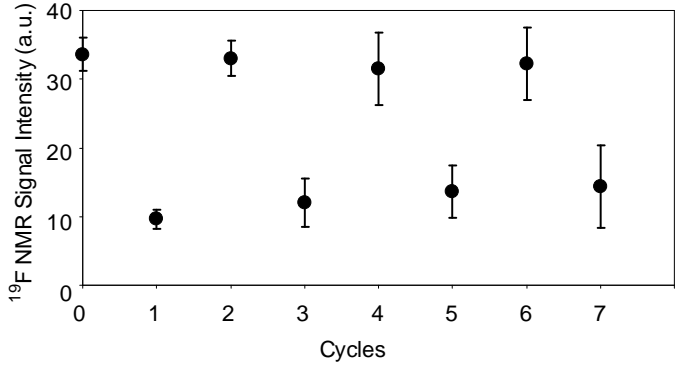

Figure 4. Signal alteration of ${ }^{19} \mathrm{~F}$ NMR during stepwise oxidation and reduction cycles was carried out in $50 \mathrm{mM}$ sodium phosphate buffer $(\mathrm{pH}$ $=7.0$ ) with $1 \mathrm{mM} \mathrm{Fc}$-POSS by the alternating addition of $2 \mathrm{mM}$ APS (odd steps) and $4 \mathrm{mM}$ ascorbic acid (even steps). Data points represent the average values obtained from three series of experiments, and the error bars represent SD values.

signal intensity of the ${ }^{19} \mathrm{~F}$ resonance. From these results, it was confirmed that these acceleration of the relaxation times could be caused by PRE. ${ }^{7}$ These data indicate that the valence state of the ferrocene moiety should be crucially responsible for the signal intensity of ${ }^{19} \mathrm{~F}$ NMR, and the signal intensity can be controlled by redox reactions. Silver tetrafluoroborate and iron(III) chloride were applicable as an oxidizer of the ferrocene moiety in Fc-POSS, and we observed similar tendency of signal alteration to APS. ${ }^{16}$

\subsection{Reversible switching of ${ }^{19}$ F NMR signals}

In order to investigate the reversibility of the switching system of Fc-POSS, oxidation of Fc-POSS and its subsequent reduction were carried out over several cycles (Figure 4). Ascorbic acid which is a mild vital reductant was used for the reduction of $\mathrm{Fc}^{+}$-POSS. The ${ }^{19} \mathrm{~F}$ NMR signal intensity was recovered after each step and found to be rapidly and fully recovered on completion of the step; thus, demonstrating the reversibility of the switching process. As a result, a fast redox $-{ }^{19} \mathrm{~F}$ NMR switch can be established on the basis of Fc-POSS by taking advantage of the properties of the ferrocene using as a magnetic switch. The reaction of $\mathrm{Fc}^{+}$-POSS with excess amounts of glutathione was carried out, however the reduction, followed by the signal recovering of ${ }^{19} \mathrm{~F}$ NMR was not observed. This result implies that this system could be applied to the selective sensing for various kinds of redox reactions in vivo by the modulation of the metal complexes in the probes.

\subsection{Stability of the probes in the buffer}

The decomposition of the complexes was followed by the decrease of the LMCT absorbance band during 250-300 $\mathrm{nm} .{ }^{16}$ For the examination of the stability of $\mathrm{Fc}^{+}$-POSS probe in water, the UV absorption monitoring of $5 \mu \mathrm{M}$ FcPOSS at 250 and $270 \mathrm{~nm}$ in the presence of $100 \mu \mathrm{M}$ APS at $25{ }^{\circ} \mathrm{C}$ was executed (Figure 5). Slight reduction of UV absorption within $24 \mathrm{~h}$ incubation represents that less degradation of $\mathrm{Fc}^{+}$-POSS should occur. Theses data suggest that the decomposition of the ferrocene moiety can be ignored through the experiments. The stability of ferrocenium state in aqueous media largely depends on the counter anion. ${ }^{16}$ It can be expected to improve the stability 


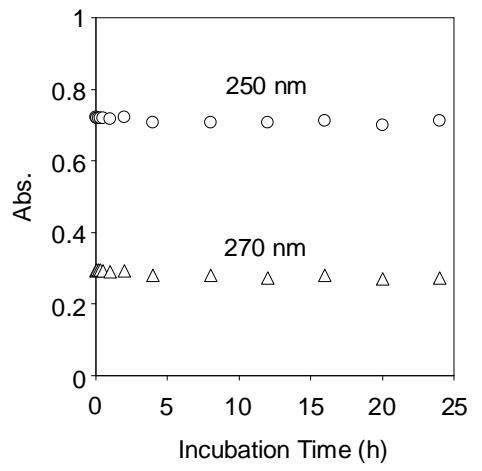

Figure 5. Stability of Fc+-POSS $(5 \mu \mathrm{M})$ in the presence of $100 \mu \mathrm{M}$ APS in $50 \mathrm{mM}$ sodium phosphate buffer $(\mathrm{pH}=7.0)$ at $25{ }^{\circ} \mathrm{C}$. $\mathrm{UV}$ absorption was monitored at $250 \mathrm{~nm}$ (circular dots) and $270 \mathrm{~nm}$ (triangular dots).

and elongate the life time of the probe by optimizing the counter anion under biological conditions.

\subsection{Bimodal detection with fluorescence and ${ }^{19}$ F NMR}

From the Stern-Volmer plots of fluorescein carboxylic acid with ferrocene carboxylic acid as a quencher, it was found that the oxidation state of ferrocene carboxylic acid has the higher quenching ability toward fluorescein carboxylic acid than that of the neutral form (Figure 6). ${ }^{23}$ Based on this phenomenon, we constructed the multimodal probe for fluorescence and a ${ }^{19} \mathrm{~F}$ NMR. ${ }^{24-32}$ We prepared the ferrocene- and fluorescein-tethered POSS (Flu-POSS), and fluorescence and ${ }^{19} \mathrm{~F}$ NMR signals of Flu-POSS were monitored in the presence or absence of APS. Figure 7 represents the results and the multimodal detection of FluPOSS-containing solutions. Both fluorescence and ${ }^{19} \mathrm{~F}$ NMR signals were decreased by the addition of APS. In contrast, slight influence of the addition of APS was observed in fluorescence emission of fluorescein carboxylic acid. These results suggest that the ferrocene moiety can work as the switch for both of NMR and fluorescence signals simultaneously. Though the sensitivity of the probe for acquiring clear signals in the ${ }^{19} \mathrm{~F}$ NMR was lower than that for the fluorescence image, our system could have a possibility to improve sensitivity by employing POSS-core dendrimers for incorporating the larger number of fluorine atoms into the probe.

\section{Conclusion}

In conclusion, we present here the reversible signal regulation of ${ }^{19} \mathrm{~F}$ NMR using the ferrocene modified POSS. Their signal intensities of ${ }^{19} \mathrm{~F}$ NMR were dominated by the valence state of the ferrocene moiety of the probe via PRE. In addition, the ferrocene moiety can also regulate the intensity of fluorescence emission nearby the fluorophore, and finally the multimodal monitoring of oxidation with ${ }^{19} \mathrm{~F}$ NMR and fluorescence was realized. Although there is room to optimize the combination of the metal complexes and the oxidizers for reducing the toxicity and enhancing the stability under biological conditions, our system has a possibility to apply for monitoring of not only the redox-

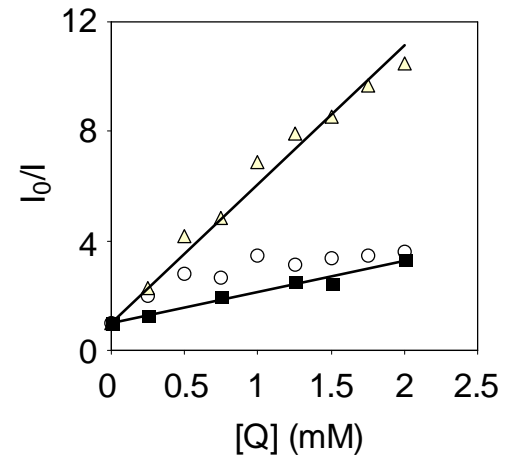

Figure 6. Stern-Volmer plots of $10 \mu \mathrm{M}$ 5(6)-fluorescein carboxylic acid in $50 \mathrm{mM}$ sodium phosphate buffer $(\mathrm{pH}=7.0)$ and $10 \%$ methanol in the presence (triangular dots) and absence (circular dots) of ferrocene carboxylic acid and APS at $25{ }^{\circ} \mathrm{C}$. Square dots were obtained from the titration of APS only. The fluorescence emission was monitored with the excitation wavelength at $490 \mathrm{~nm}$. The APS concentrations corresponded to that of 5(6)-fluorescein carboxylic acid.

a

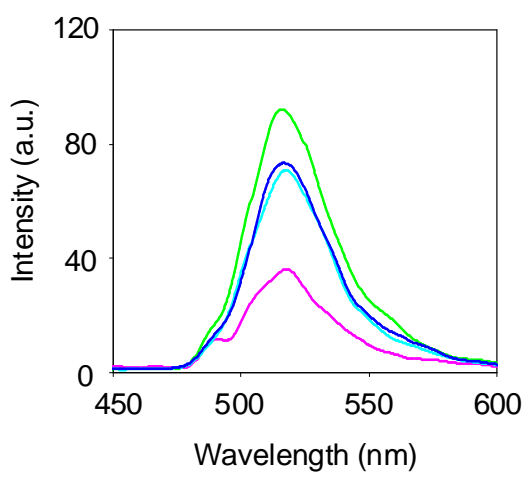

b
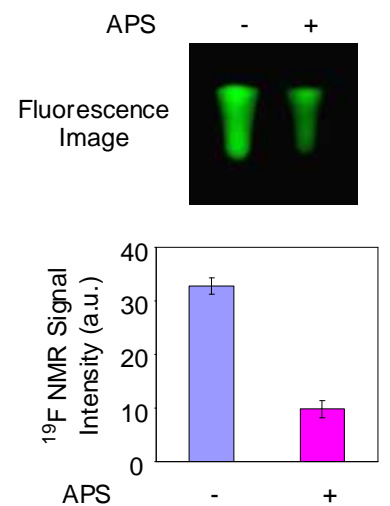

Figure 7. (a) Fluorescence spectra of the sample containing $10 \mu \mathrm{M}$ fluorescein carboxylic acid in the absence (blue line) or presence (light blue line) of $20 \mu \mathrm{M}$ APS and $10 \mu \mathrm{M}$ Flu-POSS in the absence (green line) or presence (magenta line) of $20 \mu \mathrm{M}$ APS in $50 \mathrm{mM}$ sodium phosphate buffer $\left(\mathrm{pH}=7.0\right.$ at $25{ }^{\circ} \mathrm{C}$ with the excitation at $490 \mathrm{~nm}$. (b) Multimodal detection of the sample containing Flu-POSS with fluorescence and ${ }^{19} \mathrm{~F}$ NMR spectroscopies. The fluorescence image of the same samples for the measurements of the fluorescence spectra was obtained using a transilluminator $(365 \mathrm{~nm})$. Signal intensity of ${ }^{19} \mathrm{~F}$ NMR obtained from the solution containing $1 \mathrm{mM}$ Flu-POSS in $50 \mathrm{mM}$ sodium phosphate buffer $(\mathrm{pH}=7.0)$ with or without $2 \mathrm{mM}$ APS at $25{ }^{\circ} \mathrm{C}$. Each experiment was performed in triplicate and the error bars represent SD values. 
active molecules but also other kinds of enzymes such as oxidases and reductases. In particular, for example, the detection for the differences of the redox environment between normal and cancer cells, such as the glutathione concentration or hypoxia can be expected to develop the early diagnosis methods of tumor. We can provide new strategy for molecular design of intelligent contrast agents for in vivo imaging.

\section{Experimental}

\subsection{General}

${ }^{1} \mathrm{H}$ NMR and ${ }^{13} \mathrm{C}$ NMR spectra were measured with a JEOL EX-400 (400 MHz for ${ }^{1} \mathrm{H}$ and $100 \mathrm{MHz}$ for ${ }^{13} \mathrm{C}$ ) spectrometer. ${ }^{19} \mathrm{~F}$ NMR spectra were measured with a JEOL JNM-A400 (370 MHz) spectrometer. Coupling constants $(J$ value) are reported in hertz. The chemical shifts are expressed in ppm downfield from tetramethylsilane, using residual chloroform $\left(\delta=7.24\right.$ in ${ }^{1} \mathrm{H}$ NMR, $\delta=77.0$ in ${ }^{13} \mathrm{C} \mathrm{NMR}$ ) as an internal standard and trifluoroacetic acid in $\mathrm{CDCl}_{3}$ as an external standard. All samples were incubated for $30 \mathrm{~min}$ at $25{ }^{\circ} \mathrm{C}$ before ${ }^{19} \mathrm{~F}$ NMR measurements, and NMR spectra of these solutions were obtained within $90 \mathrm{sec}$ after the accumulation of 8 scans and 4 scans as a dummy. Masses of probes were determined with a MALDI-TOF mass spectroscopy (acceleration voltage $21 \mathrm{kV}$, negative mode) with DHB (2,5-dihydroxybenzoic acid) as a matrix. Transmission electron microscopy was performed using a JOEL JEM$100 \mathrm{SX}$ operated at $100 \mathrm{kV}$.

\subsection{Preparation of Fc-POSS}

\subsubsection{Octaammonium POSS (1). ${ }^{17-20}$} Aminopropyl)triethoxysilane (100 mL, $0.427 \mathrm{~mol})$ and 35$37 \% \mathrm{HCl}(135 \mathrm{~mL})$ in $\mathrm{MeOH}(800 \mathrm{~mL})$ produced 1 as a white precipitate after 2 days at room temperature. The crude product obtained after filtration, washing with cold $\mathrm{MeOH}$, and drying. The product was spectroscopically pure in $30 \%$ yield $(18.8 \mathrm{~g})$. Recrystallization from hot $\mathrm{MeOH}$ afforded 1 (4.29 g, $3.66 \mathrm{mmol}, 6.88 \%)$ as a white solid. ${ }^{1} \mathrm{H}$ NMR $\left(\left(\mathrm{CD}_{3}\right)_{2} \mathrm{SO}, 25^{\circ} \mathrm{C}\right): \delta 8.23(\mathrm{~s}, 24 \mathrm{H}), 2.76(\mathrm{t}, 16 \mathrm{H})$, $1.71(\mathrm{~m}, 16 \mathrm{H}), 0.72(\mathrm{t}, 16 \mathrm{H}) .{ }^{13} \mathrm{C} \mathrm{NMR}\left(\left(\mathrm{CD}_{3}\right)_{2} \mathrm{SO}, 25^{\circ} \mathrm{C}\right)$ : $\delta 40.53,20.13$, and 7.96. ${ }^{29} \mathrm{SiNMR}\left(\left(\mathrm{CD}_{3}\right)_{2} \mathrm{SO}, 25{ }^{\circ} \mathrm{C}\right): \delta-$ $66.4(\mathrm{~s})$.

4.2.2. Fc-POSS (2). To a suspension of POSS 1 (1 g, 0.852 $\mathrm{mmol})$ and ethyl trifluoroacetate $(55 \mu \mathrm{L}, 0.837 \mathrm{mmol})$ in methanol $(20 \mathrm{~mL})$, triethylamine $(2 \mathrm{~mL}, 14.4 \mathrm{mmol})$ was added, and the reaction mixture was stirred at room temperature. After stirring for $3 \mathrm{~h}$, ferrocene carboxylic acid (196 mg, $3.44 \mathrm{mmol}$ ) and DMT-MM (1.92 g, $5.16 \mathrm{mmol})$ were added to the mixture. After stirring for additional $3 \mathrm{~h}$, the resulting mixture was directly dialyzed in distilled water, and the following evaporation gave the brown solid Fc-POSS (2) $1.11 \mathrm{~g}(0.613 \mathrm{mmol}, 72 \%)$ The resulting product contained statistical byproducts which have, on average, four ferrocene groups according to ${ }^{1} \mathrm{H}$ NMR spectrum. From the peak height in the MALDI-TOF MS spectra, the existing ratio was evaluated as $3: 4: 3$ (the number of the ferrocence goups as 3, 4, and 5, respectively). ${ }^{1} \mathrm{H}$ NMR (DMSO, $\left.400 \mathrm{MHz}\right) \delta 9.50$ (br, 5H), 7.95 (br, 6H), 4.67 (br, 2H), 4.41 (br, 2H), 4.19 (s, 5H), 3.14 (br, 6H), 2.76 (br, 10H), 1.69 (br, 6H), 1.55 (br, 10H), 0.68 (br, 6H), 0.60 (br, $10 \mathrm{H}$ ): ${ }^{13} \mathrm{C}$ NMR (DMSO, $\left.100 \mathrm{MHz}\right) \delta 173.2$, $155.9,117.4,70.46,69.93,69.35,68.34,41.52,40.92$, 21.76, 20.05, 8.77, 8.72: ${ }^{19} \mathrm{~F}$ NMR $\left(\mathrm{D}_{2} \mathrm{O}, 373 \mathrm{MHz}\right) \delta-$ 75.4: MALDI-TOF $\left[(\mathrm{M}(\mathrm{Fc}=3)+\mathrm{H})^{+}\right]$calcd. 1614.59 , found 1614.39, $\left[(\mathrm{M}(\mathrm{Fc}=4)+\mathrm{H})^{+}\right]$calcd. 1826.62, found 1826.97, $\left[(\mathrm{M}(\mathrm{Fc}=5)+\mathrm{H})^{+}\right]$calcd. 2038.64, found 2038.23.

4.2.3. Flu-POSS (3). To a suspension of Fc-POSS, (500 $\mathrm{mg}, 0.276 \mathrm{mmol})$, triethylamine $(2 \mathrm{~mL}, 14.4 \mathrm{mmol})$, and DMT-MM (129 mg, $0.372 \mathrm{mmol})$ in methanol $(20 \mathrm{~mL})$, fluorescein-5(6)-carboxylic acid (118 mg, $0.304 \mathrm{mmol}$ ) was added, and the reaction mixture was stirred at room temperature. After stirring for $3 \mathrm{~h}$, the resulting mixture was directly dialyzed in distilled water, and the following evaporation gave the brown solid Flu-POSS (3) (371 mg, $0.171 \mathrm{mmol}, 62 \%$ ) The resulting product contained statistical byproducts which have, on average, four ferrocene groups according to ${ }^{1} \mathrm{H}$ NMR spectrum. ${ }^{1} \mathrm{H}$ NMR (DMSO, $400 \mathrm{MHz}) \delta 9.50(\mathrm{br}, 6 \mathrm{H}), 9.41$ (br, 2H), 8.32 (br, $0.5 \mathrm{H}), 8.22$ (br, $0.5 \mathrm{H}), 8.10$ (br, $0.5 \mathrm{H}), 7.99$ (br, $0.5 \mathrm{H}), 7.85$ (br, 4H), $7.51(\mathrm{br}, 0.5 \mathrm{H}), 7.29(\mathrm{br}, 0.5 \mathrm{H}), 6.70(\mathrm{br}, 2 \mathrm{H})$, 6.51 (br, 4H), 4.61 (br, 2H), 4.32 (br, 2H), 4.13 (s, 5H), 3.11 (br, 4H), 2.73 (br, 12H), 1.64 (br, 4H), 1.51 (br, 12H), 0.68 (br, 4H), 0.57 (br, 12H): ${ }^{13} \mathrm{C}$ NMR (DMSO, $100 \mathrm{MHz}$ ) $\delta$ 173.2, 168.6, 168.5, 167.6, 166.7, 160.2, 156.2, 152.0, $136.6,133.4,131.6,131.5,130.1,129.0,127.4,127.1$, $126.4,124.9,124.0,123.4,113.0,117.5,111.7,109.6$, $102.4,87.5,87.0,70.27,69.88,69.26,68.28,41.45,40.12$, 21.76, 20.73, 9.16, 8.50: ${ }^{19} \mathrm{~F}$ NMR $\left(\mathrm{D}_{2} \mathrm{O}, 373 \mathrm{MHz}\right) \delta-$ 75.2: MALDI-TOF $\left[(\mathrm{M}(\mathrm{Fc}=3)+\mathrm{H})^{+}\right]$calcd. 1972.89, found 1972.40, $\left[(\mathrm{M}(\mathrm{Fc}=4)+\mathrm{H})^{+}\right]$calcd. 2184.92, found 2184.88, $\left[(\mathrm{M}(\mathrm{Fc}=5)+\mathrm{H})^{+}\right]$calcd. 2396.94, found 2396.18.

\subsection{CV measurements}

The current was measured in a three-electrode arrangement (ALS, model CV-50W), a glassy carbon working electrode (electrode area, $3 \mathrm{~mm}^{2}$ ), a platinum counter electrode, and an $\mathrm{Ag} / \mathrm{AgCl}$ reference electrode at $25{ }^{\circ} \mathrm{C}$. The current measurements were performed with the Fc-POSS solution $(1 \mathrm{mM})$ in the presence and absence of APS $(2 \mathrm{mM})$ in 50 $\mathrm{mM}$ sodium phosphate $(\mathrm{pH}=7.0)$. $\mathrm{CV}$ conditions were 100 $\mathrm{mV} / \mathrm{min}$ sweep speed, initial potential $0 \mathrm{~V}$, and end potential $+1.0 \mathrm{~V}$.

\subsection{Evaluation of the stability of Fc-POSS in water from the UV-vis spectrum}

The UV-vis spectrum of Fc-POSS $(5 \mu \mathrm{M})$ was taken in 50 $\mathrm{mM}$ sodium phosphate buffers $(\mathrm{pH}=7.0)$. Absorbance vs time profiles were measured at $250 \mathrm{~nm}$ using a Shimadzu UV-3600 spectrophotometer using $1 \mathrm{~cm}$ path length cell at $25{ }^{\circ} \mathrm{C}$. 


\subsection{Stepwise oxidation and reduction experiments monitored by ${ }^{19}$ F NMR}

The samples $(0.5 \mathrm{~mL})$ containing $1 \mathrm{mM}$ Fc-POSS in 50 $\mathrm{mM}$ sodium phosphate buffer $(\mathrm{pH}=7.0)$ were alternatively added to $2 \mu \mathrm{L}$ of $1 \mathrm{M}$ APS and $4 \mu \mathrm{L}$ of $1 \mathrm{M}$ ascorbic acid and then measured with ${ }^{19} \mathrm{~F}$ NMR at $25^{\circ} \mathrm{C}$.

\subsection{Fluorescence measurements of Flu-POSS}

The fluorescence emission of Flu-POSS solution $(10 \mu \mathrm{M})$ in the presence and absence of APS $(20 \mu \mathrm{M})$ under excitation at $490 \mathrm{~nm}$ was monitored using a Perkin Elmer LS50B at $25{ }^{\circ} \mathrm{C}$ using $1 \mathrm{~cm}$ path length cell. The excitation bandwidth was $1 \mathrm{~nm}$. The emission bandwidth was $1 \mathrm{~nm}$. The picture was obtained with the irradiation using the transilluminator $(365 \mathrm{~nm})$.

\section{Acknowledgments}

This study was conducted as a part of the project, "R\&D of Molecular Imaging Equipment for Malignant Tumor Therapy Support," supported by NEDO (New Energy and Industrial Technology Development Organization). We thank Prof. Y. Tsuji and Dr. T. Fujiwara for the measurement of ${ }^{19} \mathrm{~F}$ NMR.

\section{References}

1. Zimmermann, U.; Nöth, U.; Gröhn, P.; Jork, A.; Ulrichs, K.; Lutz, J.; Haase, A. Artif. Cells Blood Substit. Immobil. Biotechnol. 2000, 28, 129.

2. Yu, J.; Kodibagkar, V. D.; Cui, W.; Mason,R. P. Curr. Med. Chem. 2005, 12, 819 .

3. Higuchi, M.; Iwata, N.; Matsuba, Y.; Sato, K.; Sasamoto, K.; Saido, T. C. Nat. Neurosci. 2005, 8, 527.

4. Ahrens, E. T.; Flores, R.; Xu, H. Y.; Morel, P. A. Nat Biotechnol. 2005, 23, 983 .

5. Maki, J.; Masuda, C.; Morikawa, S.; Morita, M.; Inubushi, T.; Matsusue, Y.; Taguchi, H.; Tooyama, I. Biomaterials 2007, 28, 434.

6. Morawski, A. M.; Winter, P. M.; Yu, X.; Fuhrhop, R. W.; Scott, M. J.; Hockett, F.; Robertson, J. D.; Gaffney, P. J.; Lanza, G. M.; Wickline,S. A. Magn. Reson. Med. 2004, 52, 1255.

7. Mizukami, S.; Takikawa, R.; Sugihara, F.; Hori, Y.; Tochio, H.; Waelchli, M.; Shirakawa, M.; Kikuchi, K. J. Am. Chem. Soc. 2008, 130, 794.
8. Oishi, M.; Sumitani, S.; Nagasaki, Y. Bioconjug. Chem. 2007, $18,1379$.

9. Senanayake, P. K.; Kenwright, A. M.; Parker, D.; van der Hoorn, S. K. Chem. Commun. 2007, 2923.

10. Cui, W.; Otten, P.; Li, Y.; Koeneman, K. S.; Yu, J.; Mason, R. P. Magn. Reson. Med. 2004, 51, 616.

11. Tanaka, K.; Kitamura, N.; Chujo, Y. Chem. Commun. 2008 , 6176.

12. Tanaka, K.; Inafuku, K.; Chujo, Y. Bioorg. Med. Chem. 2008, 16,10029

13. Tanaka, K.; Kitamura, N.; Naka, K.; Morita, M.; Inubushi, T. Chujo, M.; Nagao, M.; Chujo, Y. Polym. J. 2009, 41, 287.

14. Sohn, Y. S.; Hendrickson, D. N.; Gray, H. B. J. Am. Chem. Soc. 1971, 93, 3603.

15. Köhler, F. H.; Prössdorf, W. J. Am. Chem. Soc. 1978, 100, 5970.

16. Tabbì, G.; Cassino, C.; Cavigiolio, G.; Colangelo, D.; Ghiglia, A.; Viano, I.; Osella, D. J. Med. Chem. 2002, 45, 5786.

17. Gravel, M.-C.; Laine, R. M. Am. Chem. Soc. Polym. Prepr. 1997, 38, 155

18. Feher, F. J.; Wyndham, K. D. Chem. Commun. 1998, 323.

19. Gravel, M.-C.; Zhang, C.; Dinderman, M.; Laine, R. M. Appl. Organometal. Chem. 1999, 13, 329.

20. Laine, R. M.; Choi, J.; Lee, I. Adv. Mater. 2001, 13, 800.

21. Tanaka, K.; Inafuku, K.; Naka, K.; Chujo, Y. Org. Biomol. Chem. 2008, 6, 3899.

22. Statistical byproducts which have different number of the ferrocene group were generated.

23. Fery-Forgues, S.; Delavaux-Nicot, B. J. Photoch. Photobio. A 2000, $123,137$.

24. Weissleder, R.; Pittet, M. J. Nature 2008, 452, 580.

25. Zhang, X.; Lovejoy, K. S.; Jasanoff, A.; Lippard, S. J. Proc. Natl. Acad. Sci. USA 2007, 104, 10780.

26. Alric, C.; Taleb, J.; Le Duc, G.; Mandon, C.; Billotey, C.; Le Meur-Herland, A.; Brochard, T.; Vocanson, F.; Janier, M.; Perriat, P.; Roux, S.; Tillement, O. J. Am. Chem. Soc. 2008, 130, 5908.

27. Li, C.; Winnard, Jr., P. T.; Takagi, T.; Artemov, D.; Bhujwalla, Z. M. J. Am. Chem. Soc. 2006, 128, 15072.

28. Cicchetti, F.; Gross, R. E.; Bulte, J. W. M.; Owen, M.; Chen, I.; Saint-Pierre, M.; Wang, X.; Yu, M.; Brownell, A.-L. Contrast Media Mol. Imaging 2007, 2, 130.

29. Bridot, J.-L.; Faure, A.-C.; Laurent, S.; Riviere, C.; Billotey, C.; Hiba, B.; Janier, M.; Josserand, V.; Coll, J.-L.; Vander Elst, L.; Muller, R.; Roux, S.; Perriat, P.; Tillement, O. J. Am. Chem. Soc. 2007, 129, 5076.

30. Hattori, Y.; Asano, T.; Niki, Y.; Kondoh, H.; Kirihata, N.; Yamaguchi, Y.; Wakamiya, T. Bioorg. Med. Chem. 2006, 14, 3258.

31. Janjic, J. M.; Srinivas, M.; Kadayakkara, D. K. K.; Ahrens, E. T. J. Am. Chem. Soc. 2008, 130, 2832.

32. Xia, M.; Kodibagkar, V. D.; Liu, H.; Mason, R. P. Phys. Med. Biol. 2006, 51, 45. 